\title{
Panorama da Educação Física Escolar de Porto Alegre no Ensino Médio: Estrutura e Funcionamento
}

Autora: Laura Loss Bergmann

Orientadora: Prof. Ms. Carla da Conceição Lettnin

Fomento: PIBIC/EM - CNPq

Resumo: Este estudo, descritivo exploratório, objetivou verificar como estão organizadas as aulas de Educação Física (EF) do Ensino Médio (EM) nas escolas de Porto Alegre. Para tanto, foram consultadas onze escolas, sendo cinco da rede privada e seis da rede pública (uma municipal e cinco estaduais). Os dados coletados foram adquiridos via telefone, visita às escolas ou indagação direta aos estudantes. Os questionamentos sobre a organização das aulas estavam direcionados ao gênero, às séries e às turmas. Podemos observar que a maioria das escolas pesquisadas oferece a disciplina de EF sem a integração das variáveis investigadas, ou seja, não há interação entre meninos e meninas, outras turmas ou outras séries. No Colégio de Aplicação da UFRGS (CAp/ UFRGS), a EF é estruturada de uma forma diferente em comparação com a amostra, pois as turmas na série são mescladas e constituídas pela escolha dos alunos, favorecendo a relação entre meninas e meninos. É realizado um levantamento das modalidades esportivas de preferência dos mesmos, e as quatro ou cinco mais votadas são selecionadas. Logo, observamos que este fator pode incentivar os alunos do CAp/UFRGS a participarem das aulas de EF no EM com mais interesse e envolvimento. Entretanto, ainda encontramos uma parcela dos alunos que estão à margem do processo. Por isso, a exclusão dos alunos nas aulas de EF é um assunto que ainda precisa ser investigado. A forma que as escolas estruturam a EF no EM, separando os sexos, turmas e séries, pode ser um fator preponderante à adesão às aulas.

Palavras-chave: Adesão; Educação Física; Ensino Médio; Saúde. 